九州大学学術情報リポジトリ

Kyushu University Institutional Repository

\title{
Experiments on the Control of Salinity and Sodicity in Surface : Irrigated Fields in the Upper Yellow River Valley (I)
}

Wang, We izhen

Cold and Arid Regions Environmental and Engineering Research Institute

Kobayashi, Tetsuo

Department of bioproducion Environmental Sciences, Faculty of Agriculture, Kyushu University

Yasutake, Daisuke

Faculty of Agriculture, Kochi University

Kitano, Masaharu

Department of bioproducion Environmental Sciences, Faculty of Agriculture, Kyushu University 他

https://doi.org/10.5109/10100

出版情報：九州大学大学院農学研究院紀要. 53 (1)，pp.251-256，2008-02-28. Faculty of Agriculture, Kyushu University

バージョン：

権利関係 : 


\title{
Experiments on the Control of Salinity and Sodicity in Surface-Irrigated Fields in the Upper Yellow River Valley (I)
}

\author{
Objectives and Methodology \\ Weizhen WANG ${ }^{1}$, Tetsuo KOBAYASHI*, Daisuke YASUTAKE ${ }^{2}$, Masaharu KITANO, \\ Hiroyuki $\mathrm{CHO}^{3}$, Takuya ARAKI ${ }^{4}$ and Hisashi YOSHIKOSHI
}

\author{
Laboratory of Applied Meteorology, Division of Regional Environment Science, Department of \\ Bioproduction Environmental Sciences, Faculty of Agriculture, \\ Kyushu University, Fukuoka 812-8581, Japan \\ (Received November 9, 2007 and accepted November 30, 2007)
}

\begin{abstract}
Salinity is an ever-present hazard in irrigation agriculture. In order to conduct experiments on the control of salinity and sodicity in surface-irrigated fields, an experimental field was established at Pingbu village (Baiyin, Gansu, China) located in an alluvial valley of the Yellow River in September 2007. The background to and the objectives and methodology of the experiments are described, and the natural condition of the study area and the fundamental knowledge and information on this subject are summarized.
\end{abstract}

KEY WORDS: irrigation, leaching, reclamation, salinity, sodicity, Yellow River

\section{INTRODUCTION}

In subhumid regions, where irrigation is provided on a supplemental basis, salinity is usually of little concern, because rainfall is sufficient to leach out any accumulated salts. However, in semiarid and arid regions, where irrigation is indispensable to grow the crops, salinity is an ever-present hazard and a serious problem to be solved.

The world's land surface occupies about $13.2 \times 10^{9} \mathrm{ha}$, no more than $7 \times 10^{9}$ ha of which are arable and only $1.5 \times 10^{9}$ ha of which are cultivated. Of the cultivated lands, about $0.34 \times 10^{9}$ ha $(23 \%)$ are saline and $0.56 \times 10^{9}$ ha $(37 \%)$ are sodic (Tanji, 1990).

The leaching of soluble salts from the root zone is essential in irrigated soils. Without leaching, salts accumulate in direct population to the salt content of the irrigation water and the depth of water applied. Leaching can be accomplished by ponding an appreciable depth of water on the soil surface and establishing downward water movement through soil, or drainage.

Smedema et al. (2000) estimate that $10-20 \%$ of the irrigated land is already equipped with drainage facilities; $20-40 \%$ of the irrigated area is not in need of any artificial drainage; while $40-60 \%$ is in need of drainage but remains without drainage facilities. Table 1 shows examples from countries in Central Asia and Near East to illustrate their observations.

Laboratory of Remote Sensing and GIS, Cold and Arid Regions Environmental and Engineering Research Institute, CAS, Lanzhou 730000, China

${ }^{2}$ Faculty of Agriculture, Kochi University, Nankoku 783-8502, Japan

${ }^{3}$ Department of Agricultural Sciences, Saga University, Saga 840-8502, Japan

${ }^{4}$ Laboratory of Plant Production, Division of Soil Science and Plant Production Physiology, Department of Plant Resources, Faculty of Agriculture, Kyushu University, Fukuoka 812-8581, Japan

* Corresponding author (E-mail: kotetsu@bpes.kyushu-u.ac.jp)
In the eastern block of the Luohui Irrigation Scheme (32,000 ha), Shaanxi, China, which is located in the middle Yellow River basin, salt affected area was 1,140 ha in 1953 and expanded to 4,410 ha in 1974. Although the area decreased to 3,000 ha in 1980 owing to installation of drainage facilities, it increased again to 3,910 ha in 1987 because of poor maintenance of drainage structures (Solomon et al., 2005).

The salt is also removed in the harvested crop, the relative significance of which will increase as the salt input from irrigation water decreases. Furthermore, a special case exists where leaching is severely restricted by low soil permeability and the salt content of the water is also very low. Under these conditions, salt removed from the soil in the harvested crop might conceivably become important factor determining the permanence of irrigation agriculture (USSL Staff, 1954).

The present authors conducted experiments on the development of water-saving and salinity-controlled irrigation techniques in cornfields at Togtoh (Tuoketou), Hohhot, Inner Mongolia, China, which was supported by the Core Research for Evolutional Science and Technology (CREST) program of the Japan Science and

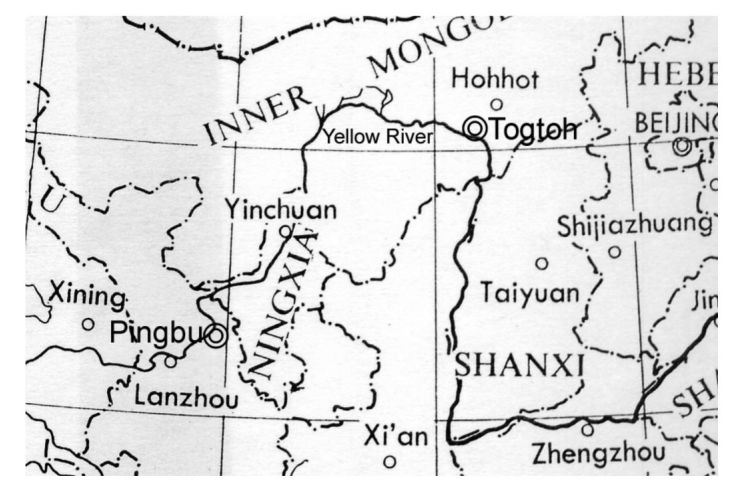

Fig. 1. Locations of Pingbu and Togtoh in the upper Yellow River valley, China. 
Table 1. Salinized and drained areas compared with total irrigated area (FAO, 2002)

\begin{tabular}{lrrrrrrr}
\hline \multirow{2}{*}{ Country } & Irrigated area & \multicolumn{2}{c}{ Salinized area } & & \multicolumn{2}{c}{ Total drained area } \\
\cline { 3 - 4 } \cline { 6 - 7 } & ha & ha & \% of irrigated area & & ha & \% of irrigated area \\
\hline Kazakhstan & 3556400 & 242000 & 6.8 & & 433100 & 12.1 \\
Kyrgyzstan & 1077100 & 60000 & 5.6 & & 149000 & 13.8 \\
Tajikistan & 719200 & 115000 & 16.0 & & 328600 & 45.7 \\
Turkmenistan & 1744100 & 652290 & 37.4 & & 1022126 & 58.6 \\
Uzbekistan & 4280600 & 2140550 & 50.0 & & 2840000 & 66.3 \\
Bahrain & 3165 & 1065 & 33.6 & & 1300 & 41.1 \\
Egypt & 3246000 & 1210000 & 37.3 & & 2931000 & 90.3 \\
Iran & 7264194 & 2100000 & 28.9 & & 40000 & 0.6 \\
Jordan & 64300 & 2277 & 3.5 & & 4000 & 6.2 \\
Kuwait & 4770 & 4080 & 85.5 & & & 2 & 0 \\
Pakistan & 15729448 & & & & & 5100165 & 32.4 \\
Syria & 1013273 & 60000 & 5.9 & & 273030 & 26.9 \\
Turkey & 4185910 & & & 3143000 & 75.1 \\
\hline
\end{tabular}

Technology Agency (JST) during a period from 2001 to 2006 (Fig. 1). Some results obtained from the experiments will be shown later. On the basis of these results they initiated the succeeding experiments on the control of salinity and sodicity in surface-irrigated fields at Pingbu, Baiyin, Gansu, China in September 2007 (Fig. 1), which is funded by a Grant-in-Aid for Scientific Research of the Japan Society for the Promotion of Science (JSPS). This paper describes the objectives and methodology of the succeeding experiments and summarizes the fundamental knowledge and information on this subject.

\section{INDICATORS OF SALINITY AND SODICITY}

\section{Salinity}

Concentration $(C)$, the amount of solute per unit volume, is typically reported in $\mathrm{mol} \mathrm{m}^{-3}$ or $\mathrm{g} \mathrm{m}^{-3}$. The units of $\mathrm{g} \mathrm{m}^{-3}$ or $\mathrm{mg} \mathrm{L}^{-1}$ are numerically equivalent to ppm. Traditionally, ion concentration has been expressed as milliequivalents per liter $\left(\mathrm{meq} \mathrm{L} \mathrm{L}^{-1}\right)$. Total salt concentration in units of $\mathrm{g} \mathrm{m}^{-3}$ is the sum of the concentrations of each ion present.

The electrical conductivity (EC hereafter represents EC normalized to $25^{\circ} \mathrm{C}$ ) of solution is often measured to estimate total salt concentration. A nearly linear relationship exists between the concentration of ions in a solution and the ability of that solution to conduct electricity. Measurements are reported in decisiemens per meter $\left(\mathrm{dS} \mathrm{m}^{-1}\right)$. The relationship between $C$ in $\mathrm{g} \mathrm{m}^{-3}$ and $\mathrm{EC}$ in $\mathrm{dS} \mathrm{m}^{-1}$ can be approximated by $C=640 \mathrm{EC}$. The value of 640 is an average value, actual values ranging from 600 to 800 (Tanji, 1990).

The amount of soluble salts in a soil can be determined or estimated by measurements made on the water extracted directly from the soil. When field soil is relatively wet, soil water samples can be extracted directly from the soil by vacuum into a porous ceramic cap buried in the soil. This technique works when the soil water potential is larger than about $-30 \mathrm{~J} \mathrm{~kg}^{-1}$ or about $-3 \mathrm{~m}$ in water head. However, it is not realistic to use this technique when the soil is relatively dry, and hence the saturation extract is recommended for appraising soil salinity. The saturation extract is obtained from a saturated soil paste that is made by adding distilled water to a sample of soil while stirring with a spatula. At saturation the soil paste glistens as it reflects light and flows slightly when the container is tipped (USSL Staff, 1954). The electrical conductivity of the saturation extract is designated as $\mathrm{EC}_{\mathrm{e}}$. However, the dilution extract of a soil sample at 1: $x$ soil-water ratio $(x=1 \sim 5)$ can be used in substitution for the saturation extract.

Kobayashi et al. (2006a) defined the electrical conductivity of the extract of a saturated soil $\left(\mathrm{EC}_{\mathrm{SAT}}\right)$ using the electrical conductivity of the dilution extract of a soil sample at 1: $x$ soil-water ratio $(x=1 \sim 5)$ as

$$
\mathrm{EC}_{\mathrm{SAT}}=\mathrm{EC}_{1: x}, \quad \text { when } x=\frac{\varepsilon \rho_{w}}{(1-\varepsilon) \rho_{S}}
$$

where $\varepsilon$ is the porosity of the soil under actual field conditions, $\rho_{S}$ is the density of soil particles and $\rho_{w}$ is the density of water. $\mathrm{EC}_{\mathrm{SAT}}$ is estimated by extraporation using such a regression equation as Eq.(2) obtained from more than three electrical conductivities of dilution extracts $\left(\mathrm{EC}_{1: x}, x=1 \sim 5\right)$.

$$
x^{n} \mathrm{EC}_{1: x}=\mathrm{EC}_{1: 1}
$$

The $\mathrm{EC}_{\mathrm{SAT}}$ is not equal to the $\mathrm{EC}_{\mathrm{e}}$, because the porosity of the saturated paste differs from that under actual field conditions, but both indices have almost the same physical meaning. Although $\mathrm{EC}_{\mathrm{e}}$ and $\mathrm{EC}_{\mathrm{MAX}}$ have merits and demerits, it can be said that $\mathrm{EC}_{\mathrm{SAT}}$ is a more practical index than $\mathrm{EC}_{\mathrm{e}}$ is, because the former can be measured

Table 2. Scale of electrical conductivity $\left(\mathrm{EC}_{\mathrm{e}}\right.$ or $\mathrm{EC}_{\mathrm{SA}}$, $\left.\mathrm{dS} \mathrm{m}^{-1}\right)$

\begin{tabular}{lllll}
\hline 0 & 2 & 4 & 6 & 8 \\
\hline $\begin{array}{l}\text { Salinity effects } \\
\text { mostly negligible }\end{array}$ & $\begin{array}{l}\text { Yields of very sensitive } \\
\text { crops may be restricted }\end{array}$ & $\begin{array}{l}\text { Yields of many } \\
\text { crops restricted }\end{array}$ & $\begin{array}{l}\text { Only tolerant crops } \\
\text { yield satisfactorily }\end{array}$ & $\begin{array}{l}\text { Only a few very tolerant } \\
\text { crops yield satisfactorily }\end{array}$ \\
\hline
\end{tabular}


not only in the laboratory without special apparatuses such as a vacuum pump but also in the field automatically and continuously (Wang et al., 2005); furthermore, it can be compared at first hand to the electrical conductivity of groundwater when water and salt movements in the soil profile are analyzed.

The scale shown in Table 2 is recommended for general use in appraising the effect of soluble salts on crops (USSL Staff, 1954). A soil is classed as normal with respect to salinity when $\mathrm{EC}_{\mathrm{e}}$ or $\mathrm{EC}_{\mathrm{SAT}}$ is smaller than $4 \mathrm{dS} \mathrm{m}^{-1}$.

\section{Sodicity}

When the concentration of sodium becomes excessive relative to the concentration of calcium plus magnesium, a soil or water is said to be sodic. As sodium concentration increases, soil mineral particles will swell and disperse causing water movement into and through the soil to decrease, because sodium ion is univalent and the effective thickness of the diffuse double layer is larger than that produced by bivalent ions such as calcium and magnesium (Bolt and Bruggenwert, 1976). Therefore, high sodium concentrations reduce infiltration so that the crop is not adequately applied with water. Furthermore, the reduction in hydraulic conductivity makes drainage poor.

The ability to predict the distribution of ions between the soil solution and the exchanger phase is vital when dealing with a potential sodic hazard. The sodium adsorption ratio (SAR) of solution is a good indicator of the sodium status or sodicity. SAR is defined as

$$
\mathrm{SAR}=\frac{C_{\mathrm{Na}}}{\left(C_{\mathrm{Ca}}+C_{\mathrm{Mg}}\right)^{1 / 2}}
$$

where $C$ is in $\mathrm{mol} \mathrm{m}^{-3}, \mathrm{Na}, \mathrm{Ca}$ and $\mathrm{Mg}$ refer to sodium, calcium and magnesium. If units are meq $\mathrm{L}^{-1}$, the sum $C_{\mathrm{Ca}}+C_{\mathrm{Mg}}$ must be divided by two before taking the square root.

The ratio of ions adsorbed by the exchanger in the soil are approximately expressed as (USSL Staff, 1954):

$$
\frac{[\mathrm{NaX}]}{\left[\mathrm{CaX}_{2}+\mathrm{MgX}_{2}\right]}=k_{g}^{\prime} \frac{C_{\mathrm{Na}}}{\left(C_{\mathrm{Ca}}+C_{\mathrm{Mg}}\right)^{1 / 2}}=k_{g}^{\prime} \mathrm{SAR}
$$

where $\mathrm{X}$ is one mole of negative charge on the exchanger in the soil, square bracket [...] indicates the concentration adsorbed by the exchanger, and $k_{g}$ ' is the modified Gapon selectivity coefficient $\left(\mathrm{mol} \mathrm{m} \mathrm{m}^{-3}\right)^{-1 / 2}$, which ranges from 0.008 to $0.016\left(\mathrm{~mol} \mathrm{~m}^{-3}\right)^{-1 / 2}$ and 0.015 (mol $\left.\mathrm{m}^{-3}\right)^{-1 / 2}$ is widely used (Tanji, 1990).

Because $\mathrm{Ca}, \mathrm{Mg}$, and $\mathrm{Na}$ are the most common exchangeable cations in arid soils, Eq.(4) may be simplified to

$$
\frac{[\mathrm{NaX}]}{\mathrm{CEC}-[\mathrm{NaX}]}=k_{g}^{\prime} \mathrm{SAR}=\mathrm{ESR}
$$

where CEC is the cation exchange capacity, or the total exchangeable cations when anion exclusion is negligible (Bolt and Bruggenwert, 1976), and ESR is called the exchangeable sodium ratio.

It is often convenient to express the relative amounts of various exchangeable cations present in a soil as a percentage of CEC. The exchangeable sodium percentage (ESP) is equal to 100 times the exchangeable sodium content [NaX] divided by CEC if both contents are expressed in the same units, or

$$
\mathrm{ESP}=\frac{100[\mathrm{NaX}]}{\mathrm{CEC}}
$$

In terms of ESP, Eq.(5) becomes

$$
\frac{\mathrm{ESP}}{100-\mathrm{ESP}}=k_{g}^{\prime} \mathrm{SAR}
$$

Therefore the relation between ESP and SAR is approximately given as

$$
\mathrm{ESP}=\frac{100 k_{g}^{\prime} \mathrm{SAR}}{1+k_{g}^{\prime} \mathrm{SAR}} \approx \frac{1.5 \mathrm{SAR}}{1+0.015 \mathrm{SAR}}
$$

A soil is classed as normal with respect to sodicity when ESP is smaller than 15.

\section{SOME RESULTS OF TOGTOH EXPERIMENTS}

Experiments were conducted at Togtoh, Inner Mongolia, on the development of water-saving and salinity-controlled irrigation techniques during a period from 2001 to 2006. The results obtained for the subjects related to salinity and sodicity of soil and water are summarized as follows:

Irrigated lands in the Yellow River valley are studded with saline plots of various sizes. These plots occur because 1) the water table is shallow due to the large quantity of water applied for irrigation, and 2) spatial variations in evaporation and infiltration related to spatial variations in soil texture leads to spatial variations in groundwater salinity. Saline plots form only over shallow aquifers that hold highly saline water. Accordingly, the expansion of salt-affected fields can be arrested by preventing over-irrigation and an associated rise in the water table, and by reducing the groundwater salinity in saline plots by some method. It would probably be effective to pump high-salinity groundwater out from saline plots to lower the water table and to induce the flow of low-salinity groundwater into the plot from surrounding areas.

Salts accumulate in the root zone by soil surface evaporation and crop transpiration, and some of salts are removed from the root zone by plants. As plant roots selectively absorb nutrients or ions from soil solution, the concentrations of ions change as water moves from the irrigation canal through the field soil, and across the roots to the shoots. The xylem sap exuded from stem stumps of corn was collected and concentrations of various ions were measured. Similar measurements of the ions were also undertaken for samples of water from the Yellow River, irrigation water, and the groundwater in the study field. The concentration of sodium in the exudate was very small, indicating that sodium was not actively absorbed with the corn plants. Hence, sodium must accumulate in the groundwater and soil and results in the production of sodic soils. 


\section{NATURAL ENVIRONMENT OF PINGBU VILLAGE}

Pingbu village in Jingyuan prefecture, Baiyin, Gansu, is located on the right bank of the Yellow River (N36 ${ }^{\circ}$ 25.5', E104 ${ }^{\circ} 25.4^{\prime}, 1461 \mathrm{~m} \mathrm{ASL}$ ) (Fig. 1). Table 3 lists the climatic characteristics of Jingyuan. Fig. 2 shows the seasonal change in precipitation at Jingyuan averaged over the period from 1951 to 2000 . The study region is judged to be located on the margin of a semiarid continental monsoon climate, and the monsoon arrives early in July and ends in late August.

Table 3. Climatic characteristics of Pingbu (Jingyuan, 19512000)

\begin{tabular}{lclr}
\hline Climatic element & Max & Min & Mean \\
\hline Annual precipitation $(\mathrm{mm})$ & 417 & 135 & 238.3 \\
Air temperature $\left({ }^{\circ} \mathrm{C}\right)$ & 32.0 & -19.3 & 8.9 \\
\hline
\end{tabular}

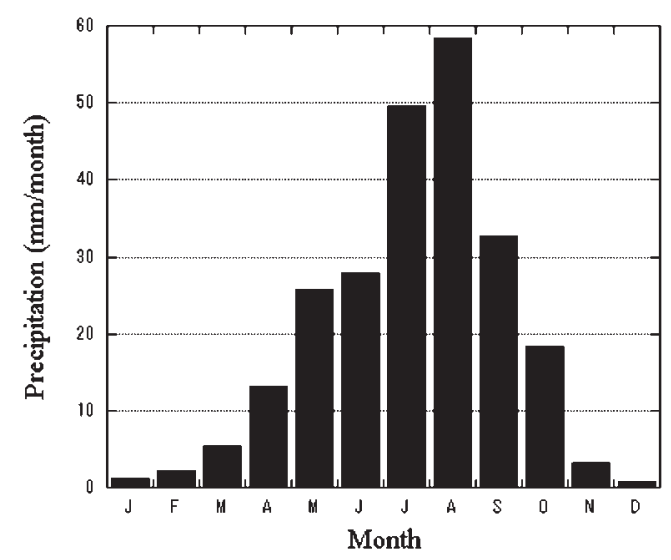

Fig. 2. Seasonal change in precipitation at Jingyuan (1951-2000).

An experimental field was established at Jiangtan section of Pingbu village, which is located in an alluvial valley of the Yellow River, and a cliff of the yellow loess about $150 \mathrm{~m}$ high rises about $500 \mathrm{~m}$ southeast of the field. There are also cultivated fields on the river terrace extending from the edge of the cliff toward the back mountainous region and corn is grown there using the water pumped up from the Yellow River. The outline of the observation system installed at this field is described in a companion paper (Yoshikoshi et al., this issue).

Saline seeps occur at the foot and wall face of the cliff. The water that seeped from the foot was clear and its EC was $52.0 \mathrm{dS} \mathrm{m}^{-1}$ on $19 \mathrm{Sep} .2007$, while the water that seeped from a horizontal narrow crack on the wall face was muddy and its EC was $47.3 \mathrm{dS} \mathrm{m}^{-1}$ on 12 Aug. 2007. These saline seep waters are collected to a drain ditch next to the cliff that leads to the Yellow River. It is said that a saline seep results from a salinization process, often accelerated by dryland farming, which allows water to move through salt-laden substrata below the root zone (Tanji, 1990). The state of salinization and alkalization in and around the experimental field is shown elsewhere (Yasutake et al., this issue).

The crops grown in and around the experimental field are mostly corn and rice, which are staple farm products of Pingbu village along with vegetables and apples. Jiangtan section in which the experimental field is established is located downriver in Pingbu village extending along the Yellow River and is seriously affected by salinization compared to the upriver sections. The cause of this seems to be that the irrigation water is taken at the upriver tip of the village from the Yellow River and flows down along a few canals through the village; as a result, water table is shallow and drainage is poor in this downriver section. Although the saline sheep water is collected to the ditch next to the cliff, it seems possible that the dispersion of the salts originated from the saline seeps partly causes salinization in this section.

\section{OBJECTIVES OF PINGBU EXPERIMENTS}

\section{Soil physical reclamation}

Leaching is the usual way to reclaim salt-affected soils, since soil surface evaporation and plant uptake leave significant amounts of salt in the soil profile. Thus, soils to be reclaimed by leaching must be permeable and have outlets for drainage. When fields consist of several types of soils, leaching takes place first in sandy portions, then, in clay-rich portions (Miyamoto and Cruz, 1986). Furthermore, when a shallow water table exists, groundwater moves upward by capillary action more in clay-rich portions than in sandy portions. Thus, salts tend to accumulate more in the soil profile consisting of fine-textured soils than in coarse-textured soils, and saline spots are formed in clay-rich portions (Kobayashi et al., 2006b).

Because it is difficult to improve leaching of soil profiles consisting of fine-textured soils, reclamation of saline spots can be accomplished by reducing the amount of upward movement of groundwater from the water table and/or by improving the quality of groundwater underlying the spots. Kobayashi et al. (2006b) proposed the PSW-Well (Pumping high-salinity groundwater out of a well) method.

The principle of the PSW-Well method is schematically depicted in Fig. 3. When groundwater of high

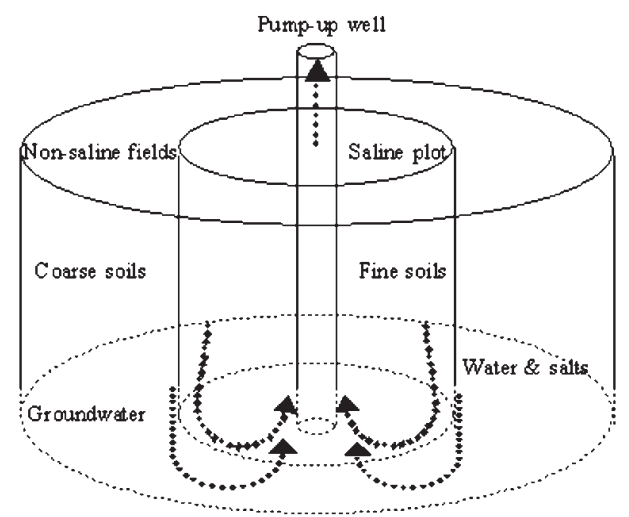

Fig. 3. Schematic representation of the principle of the PSW-Well method. 
salinity is pumped out of a well dug in a saline spot, the water table will fall and the groundwater of low salinity in the surrounding areas consisting of coarse-textured soils will be induced to flow into the plot. As a result, even if leaching is as poor as before, reclamation of the saline plot is expected to proceed because the input of soluble salts to the soil profile from the water table should decrease.

One of the objectives of the Pingbu experiments is to validate this idea against experimental data obtained in the field. Although this method is based on the assumption that groundwater is at rest and there are spatial variations in groundwater salinity in and around the experimental field (Kobayashi et al., 1006b), this assumption has not been tested experimentally yet in the present study area. Therefore, it is not sure that when water table goes down by pumping, whether or not the salinity of the groundwater that flows into the spot from surrounding areas is lower than that of the groundwater pumped out of the spot. The field experiment on this subject is due to be conducted in 2008 .

\section{Biological reclamation}

As shown above, sodium accumulates in the groundwater and soil owing to the cultivation of corn and results in the production of sodic soils. Recently the area under corn cultivation has increased all over the world, not excepting in China. Although it is believed that plant uptake removes insignificant amounts of salts, the salt content of irrigation water diverted from the

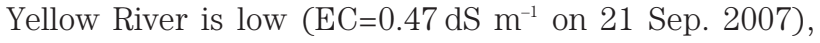
and soil permeability is also low (Yoshikoshi et al., this issue). Therefore, as mentioned above, salt removed from the soil in the harvested crop might become important factor in this area. Irshad et al. (2005) reviewed the use of halophytes for the reclamation of saline wastelands.

Another objective of the Pingbu experiments is to test various crops on their selective absorptivity for nutrients or ions from soil solution. Reclamation of sodium-affected soils usually involves replacing exchangeable $\mathrm{Na}^{+}$with $\mathrm{Ca}^{2+}$ and $\mathrm{Mg}^{2+}$. However, in this experiment, passive means for reducing $\mathrm{Na}^{+}$in soil solution by using cultivation techniques such as mixed crops or crop rotation will be investigated.

\section{CONCLUDONG REMARKS}

Irrigated agriculture presently accounts for about $40 \%$ of the world's production of food and fiber and it is anticipated that it will need to produce nearly $50 \%$ by the year 2040 (FAO, 1988). However, extensive areas of irrigated land have been degraded by salinization and waterlogging resulting from over-irrigation and others. The present rate of such degradation has surpassed the present rate of expansion in irrigation (FAO, 1999). Therefore, the development of the technique for reclaiming saline-affected and/or sodium-affected soils is essential for increasing food production enough for an increase in population in future.
The Pingbu experiments started in September 2007 and the village people expect that the technological measures for reclaiming their saline wastelands will be developed. To get the data on hydrological and meteorological conditions closely connected with soil salinization, an observation system was installed at the experimental field and the calibration of the system has been carried out. The outline of the system and the results of calibration are shown in a companion paper (Yoshikoshi et al., this issue).

\section{ACKNOWLEDGEMENTS}

The authors wish to thank Prof. X. Li of the Cold and Arid Regions Environmental and Engineering Research Institute, CAS, for his cooperation.

This research is funded by a Grant-in-Aid for Scientific Research of the Japan Society for the Promotion of Science (JSPS) during a period from 2007 to 2009 (No. 19405039).

\section{REFERENCES}

Bolt, G. H. and M. G. M Bruggeenwert 1976 Soil Chemistry. Elservier, Amsterdam

FAO 1988 World Agriculture Toward 2000: A FAO Study. Bellhaven Press, London

FAO 1999 Soil Salinity Assessment. Methods and interpretation of electrical conductivity measurements. FAO Irrigation and Drainage Paper 57, FAO, Rome

FAO 2002 Agricultural Drainage Water Management in Arid and Semi-Arid Areas. FAO Irrigation and Drainage Paper 61, FAO, Rome

Irshad, M., T. Endo, T. Honna, S. Yamamoto and A. E. Eneji 2005 The reclamation of saline wastelands by halophytes. J. Arid Land Studies, 14: 199-207

Kobayashi, T., W. Wang, Y. Ikawa, H. Cho and W. He 2006a An easily measurable and practical index of soil salinity. $J$. Japan Soc. Hydrol. \& Water Resour., 19: 183-188

Kobayashi, T., H. Cho, T. Kaneko, W. Wang and D. Yokoyama 2006b A survey of the relationship between soil salinization and soil texture in the upper Yellow River basin. Kyushu J. Agric. Meteorol., II, 15: 1-6

Miyamoto, S. and I. Cruz 1986 Spatial variability and soil sampling for solinity and sodicity in surface-irrigated orchards. Soil Sci. Soc. AM. J., 50: 1020-1026

Solomon, H., Y. Kitamula, Z. Li, S. Yamamoto, S. Yang, S. Li, P. El-Hassan, W. A. and Otagaki, K. 2005 Classification of salinization processes in Luohui irrigation scheme, China. J. Arid Land Studies, 15: 89-95

Tanji, K. K. 1990 Agricultural Salinity Assessment and Management. American Society of Civil Engineers, New York

USSL Staff 1954 Saline and Alkali Soils. Agriculture Handbook No.60, US Department of Agriculture, Washington D.C.

Wang, W., E. Watanabe, T. Kobayashi, H. Cho, W. He and N. Mohri 2005 A method for measuring soil solution electrical conductivity in the field using TDR. J. Japan Soc. Hydrol. \& Water Resour., 18: 55-63

Yasutake, D., T. Araki, M. Kitano, W. Wang, K. Urayama, H. Cho and T. Kobayashi 2008 Experiments on the control of salinity and sodicity in surface-irrigated fields in the upper Yellow River valley (III). The state of salinization and alkalization in and around the experimental field. J. Fac. Agr. Kyushu Univ., 52: 265-270

Yoshikoshi, H., W. Wang, H. Cho, T. Araki, D. Yasutake, J. Zhou. 
K. Urayama, Y. Wu, T. Kobayashi and M. Kitano 2007 Experiments on the control of salinity and sodicity in surface-irrigated fields in the upper Yellow River valley (II).
Observation system and calibration. J. Fac. Agr. Kyushu Univ., 52: 257-263 